\title{
РИСКИ ВОЗНИКНОВЕНИЯ МИКОТОКСИКОЗОВ РЫБ В УСЛОВИЯХ АКВАКУЛЬТУРЫ
}

\author{
(обзор)
}

\section{Г.П. КОНОНЕНКО ${ }^{\bowtie}$, Д.А. ОНИЩЕНКО, М.И. УСТЮЖАНИНА}

Современная аквакультура рыб относится к масштабным и стремительно развивающимся отраслям мирового производства (FAO, 2018). С целью повышения качества выращиваемой продукции активно ведется поиск эффективных способов контроля безопасности искусственных кормов (J. Bostock с соавт., 2010). По результатам мониторинговых проектов, выполненных в Аргентине, Бразилии, США, Китае, Корее и странах Центральной Европы (С. Pietsch с coавт., 2013; B.T.C. Barbosa с соавт., 2013; M. Greco с соавт., 2015; L. Pinotti с соавт., 2016), ситуация по загрязненности комбикормов для рыб микотоксинами признана чрезвычайно серьезной как по распространенности и содержанию, так и по сочетанной встречаемости (I. Matejova c coaвт., 2017; C. Pietsch, 2019). В российском рыбоводстве, которое в последние годы стало многопрофильным направлением сельского хозяйства, специалистами академической и вузовской науки, а также отраслевых НИИ разработаны рецептуры комбикормов, учитывающие возрастные и видовые особенности рыб (Ю.А. Желтов, 2006; В.Я. Скляров, 2008; И.Н. Остроумова, 2012; Гамыгин Е.А. с соавт., 2013), и подробно рассмотрена проблема их микробной контаминации (И.В. Бурлаченко, 2008). В Российской Федерации для комбикормовой продукции введены обязательные требования на соответствие показателям качества и безопасности (ГОСТ 10385-2014) и создана современная методическая база для проведения микотоксикологического контроля (ГОСТ 31653-2012, ГОСТ 31691-2012, ГОСТ 32587-2013, ГОСТ 34108-2017, ГОСТ Р 51116-2017). Цель настоящего обзора - актуализация сведений о контаминации микотоксинами сырья для производства аквакормов, обобщение мировых данных по характеру острого действия наиболее вероятных контаминантов, а также анализ клинических признаков, патологоанатомических и биохимических изменений, сопровождающих острые и хронические микотоксикозы рыб. За последние годы получены убедительные подтверждения того, что в группу наиболее распространенных контаминантов отечественных сырьевых ингредиентов (пшеничной, ячменной и кукурузной муки, отрубей, подсолнечного жмыха и шрота) входят Т-2 токсин, дезоксиниваленол, фумонизины группы В и зеараленон, относящиеся к фузариотоксинам, а также альтернариол, охратоксин А, цитринин, циклопиазоновая кислота, микофеноловая кислота и эмодин (Г.П. Кононенко с соавТ., 2018, 2019). Анализ массива мировых данных по экспериментальным микотоксикозам карпа обыкновенного (Cyprinus carpio), канального сома (Ictalurus punctatus), амура белого (Ctenopharyngodon idella), нильской тиляпии (Oreochromis niloticus), радужной форели (Oncorhynchus mykiss), атлантического лосося (Salmo salar) разных возрастных групп показывает, что фузариотоксины следует причислить к ключевым факторам риска и направить усилия на определение их безопасных пороговых значений. Интоксикации, вызванные охратоксином А, остаются недостаточно изученными, а ситуация в отношении остальных возможных контаминантов комбикормового сырья - неясной. Обоснованные предложения по регламентации количества микотоксинов в кормах для рыб приведены лишь по Т-2 токсину для карпа обыкновенного (В.Т. Галаш, 1988), дезоксиниваленолу для белого амура (С. Huang с соавт., 2018, 2019, 2020) и атлантического лосося (А. Bernhoft с соавт., 2018), фумонизину В1 для канального сома (M.N. Li с соавт., 1994, S. Lumlertdacha с соавт., 1995). Данные по степени сохранения этих микотоксинов в тканях рыб ограничены (C. Pietsch с соавт., 2014, 2015; А. Ananter с соавт., 2016), поэтому регламенты по их остаточным количествам в продукции до сих пор не приняты. Однако поиск новых подходов к корректной оценке последствий негативного действия микотоксинов и трансмиссии в рыбную продукцию продолжается.

Ключевые слова: аквакультура, микотоксикозы рыб, кормовое сырье, комбикорма, микотоксины.

Современная аквакультура - стремительно развивающаяся отрасль мирового производства, общая рыночная стоимость ее продукции в ценах первоначальных продаж в 2016 году достигла 232 млрд долларов США (1). Особенно активно ведется поиск новых форм, методов, приемов, технологических решений и нетрадиционных подходов, направленных на повышение эффективности искусственного выращивания рыбы и расширение ее ассортимента (2). Важность исследований микотоксинов в кормах для рыб 
впервые стала очевидной в начале 1960-х годов, когда в США при использовании хлопковой муки были зарегистрированы массовые вспышки афлатоксикоза радужной форели, сопровождающиеся развитием гепатоцеллюлярных карцином (3). Последующий опыт наблюдений и экспериментов показал, что другие микотоксины также негативно воздействуют на непромысловую рыбу, вызывая разную степень интоксикации и специфические проявления (4-6).

В каждой стране благополучие кормов для рыб связано главным образом с характером контаминации микотоксинами ингредиентов растительного происхождения - основных источников протеина для рыб низких трофических уровней. Мониторинговые исследования, выполненные в Аргентине, Бразилии, США, Китае, Корее и странах Центральной Европы (7-10), позволили не только оценить реальную ситуацию в национальном рыбоводстве этих стран, но и получить целостное представление об общих масштабах угрозы. Загрязненность кормов микотоксинами признается чрезвычайно высокой по распространенности, содержанию, сочетанной встречаемости и, по мнению ведущих мировых экспертов, приводит к значительным экономическим потерям $(11,12)$.

Благодаря государственной поддержке (13), российское рыбоводство за последние годы стало развитым многопрофильным направлением сельского хозяйства, основное место в котором занимают карповые, растительноядные и лососевые рыбы. Отечественными учеными разработаны сбалансированные рецепты комбикормов, учитывающие возрастные и видовые особенности рыб, рекомендован порядок их использования, правила контроля качества (14-17) и подробно рассмотрены риски, связанные с микробной контаминацией (18). Однако работы по изучению действия микотоксинов на эти организмы немногочисленны, а попытки систематизировать информацию, необходимую для специалистов, носят весьма общий характер $(19,20)$.

Цель настоящего обзора - актуализация сведений о контаминации микотоксинами сырья для производства аквакормов, обобщение мировых данных по характеру острого действия наиболее вероятных контаминантов, а также анализ клинических признаков, патологоанатомических и биохимических изменений, сопровождающих острые и хронические микотоксикозы рыб.

Сырье растительного происхождения в рецептах отечественных комбикормов представлено в основном пшеничной, ячменной и кукурузной мукой, отрубями, а также подсолнечным жмыхом и шротом $(14,16$, 17). Для зерна, предназначенного на кормовые цели, характерна контаминация фузариотоксинами с обширной встречаемостью Т-2 токсина (Т-2) и дезоксиниваленола (ДОН), иногда совместно с зеараленоном (ЗЕН); в зерне кукурузы часто обнаруживается фумонизин В1 (ФУМ В1) (21-25). Кроме того, установлена очаговая загрязненность зерна охратоксином А (OA) (26), а в зерне пшеницы, кукурузы и в кормовой продукции из переработанных семян подсолнечника выявлены частые случаи совместного обнаружения OA и цитринина $(27,28)$. Типичные контаминанты подсолнечного жмыха и шрота - ОА и альтернариол, а также цитринин, циклопиазоновая кислота, микофеноловая кислота и эмодин (29). Афлатоксины, с которыми связывают основную опасность для сектора аквакультуры в большинстве стран африканского и азиатско-тихоокеанского регионов (30), в российском комбикормовом сырье крайне редки, поэтому в настоящей работе не 
рассматриваются.

Микотоксины, актуальные для рыбных комбикормов в нашей стране, стали предметом исследований в 1970-1990-е годы, когда были установлены их летальные дозы и обнаружены межвидовые различия рыб по восприимчивости к ним (табл. 1).

1. Летальные для различных видов рыб дозы микотоксинов при однократном пероральном (ро) и внутрибрюшинном (iр) введении

\begin{tabular}{|c|c|c|c|}
\hline Вид & Микотоксин & $\begin{array}{l}\text { Летальная доза, } \\
\text { мг/кг массы }\end{array}$ & Ссылка \\
\hline Карп обыкновенный (Cyprinus carpio) & Т-2 токсин & $\begin{array}{l}\text { ip LD50 }=0,21 \pm 0,01 \\
\text { po } \operatorname{LD}_{50}=0,46 \pm 0,04\end{array}$ & (31) \\
\hline Индийский карп (Labeo rohita) & Цитринин & ip $\mathrm{LD}_{100}=12,5$ & (32) \\
\hline Канальный сом (Ictalurus punctatus) & Циклопиазоновая кислота & ip $\mathrm{LD}_{50}=2,82$ & (33) \\
\hline \multirow[t]{2}{*}{ Радужная форель (Oncorhynchus mykiss) } & Т-2 токсин & po $\mathrm{LD}_{50}=5,37 \pm 0,40$ & $(31)$ \\
\hline & Охратоксин А & ip $\mathrm{LD}_{50}=4,7$ & (34) \\
\hline
\end{tabular}

В этих же ранних работах впервые были описаны характерные повреждения, сопровождающие острые интоксикации после инъекций и перорального введения. Под действием Т-2 у карпа обыкновенного (Cyprinus carpio) некротические явления распространялись на гепатопанкреас, почки, передний и средний отделы кишечника, особенно сильно проявляясь в стенках кровеносных сосудов, жабрах, заднем отделе кишечника. При этом смертельный эффект на особей разных возрастных групп был одинаковым (31). У подросшей молоди индийского карпа роху (Labeo rohita) в ответ на воздействие цитринина в дозах 12,5 и 25,0 мг/кг обнаруживались приводящие к гибели повреждения почек, печени и желудка с депигментацией и гиперемией хвостового плавника (32). По действию на канального сома (Ictalurus punctatus) с массой 19 г циклопиазоновая кислота была охарактеризована как нейротоксин: через 30 мин после ее инъекций в дозе от 2,4 мг/кг и больше у рыб наблюдались сильные конвульсии и тетанические судороги (33). У радужной форели (Oncorhynchus mykiss) OА вызывал некроз клеток канальцев почек и печени (34).

Изучение последствий длительного алиментарного поступления микотоксинов, которое обеспечивалось за счет диет с добавлением естественно контаминированных ингредиентов или биомассы грибов-продуцентов, позволило представить картину нарушений в состоянии рыб в условиях, приближенных к реальным. Было установлено, при каком содержании микотоксинов в кормах у карпа обыкновенного и канального сома происходит ухудшение морфологических и рыбоводных показателей - уменьшение кондиционности, возрастание затрат корма, снижение жизнестойкости (табл. 2).

2. Содержание микотоксинов в кормах, приводящее к негативному действию на морфологические и рыбоводные показатели у двух видов рыб

\begin{tabular}{|c|c|c|c|c|}
\hline $\begin{array}{l}\text { Микотоксин, форма внесения } \\
\text { (сопутствующие микотоксины) }\end{array}$ & $\begin{array}{l}\text { Возраст, } \\
\text { начальная } \\
\text { масса рыб, Г }\end{array}$ & $\begin{array}{l}\text { Срок } \\
\text { кормления }\end{array}$ & $\begin{array}{l}\text { Содержание ток- } \\
\text { сина, мг/кг корма }\end{array}$ & Ссылки \\
\hline \multicolumn{5}{|c|}{ К арп обыкновенный (Cyprinus carpio) } \\
\hline $\begin{array}{l}\text { Fusarium sporotrichioides (НТ-2 токсин, } \\
\text { неосоланиол) }\end{array}$ & Не указано & 67 сут & 0,$14 ; 1,02$ & $(31)$ \\
\hline Т-2 токсин, культуральный материал & & & & \\
\hline $\begin{array}{l}F \text {. sporotrichioides (НТ-2 токсин, неосоланиол) } \\
\text { Т-2 токсин, культуральный материал }\end{array}$ & Не указано & 122 сут & 0,$45 ; 0,92$ & $(31)$ \\
\hline F. sporotrichioides (НТ-2 токсин, 0,45 мг/кг) & 1 год, 23 г & 4 нед & 4,11 & $(35)$ \\
\hline Т-2 токсин, препарат & Не указано & 4 нед & 5,3 & $(36)$ \\
\hline Дезоксиниваленол, контаминированное сырье & Сеголетки & 30 сут & 1,25 & $(37)$ \\
\hline Дезоксиниваленол, контаминированное сырье & Двухлетки & $2,5 \mathrm{Mec}$ & 1,25 & $(37)$ \\
\hline
\end{tabular}


Дезоксиниваленол, культуральный материал $F$. graminearum (15-ацетилдезоксиниваленол,

$0,33 \mathrm{мг} / \mathrm{кг)}$

Фумонизин В1, препарат

Фумонизин В1, препарат

Т-2 токсин, препарат

К а нальны й с о

1 год, 23 г 4 нед

1 год 42 су

1 год 42 сут

м (Ictalurus punctatus)

Дезоксиниваленол, контаминированное сы-

рье

Фумонизин В1, культуральный материал

F. moniliforme

Фумонизин В1, культуральный материал

F. moniliforme

Фумонизин В1, культуральный материал

F. moniliforme

Охратоксин А, культуральный материал

Aspergillus ochraceus

Циклопиазоновая кислота, препарат

\section{Молодь, 8,9 г}

Молодь, 5 г

1 год, 1,2 г

Молодь, 6,1 г

2 года, 31 г

Молодь, 6,1 г

Молодь, 7,5 г
5,96

0,$5 ; 5,0$

$10 ; 100$

0,$625 ; 1,25 ; 2,5$

$15 ; 17,5$

$20 ; 80 ; 320 ; 720$

$(42,44)$

$80 ; 320 ; 720$

$1 ; 4 ; 8$

0,1

(33)

Так, в прудах при 67-суточном скармливании карпу обыкновенному 0,14 и 1,02 мг/кг Т-2 наблюдалось снижение массы рыбы на 30 \% и 2-кратное возрастание затрат корма за сезон на единицу прироста. В бассейнах у рыбы, получавшей в течение 122 сут корм с Т-2 в дозах 0,45 мг/кГ и 0,92 мг/Кг, рост почти полностью прекращался, и средняя масса к концу опытного периода была на 40-50 \% меньше, чем в контроле (31). У канального сома снижение приростов было отмечено при содержании Т-2 и ОА $\leq$ 1 мг/кг $(39,44)$ и циклопиазоновой кислоты 0,1 мг/кг (33).

У молоди нильской тиляпии (Oreochromis niloticus) с начальной массой 2,7 г снижение прироста наблюдали при 8-недельном скармливании корма, содержащего ФУМ В1 из культуры гриба в количествах 40, 70 и 150 мг/кг (46). У взрослых особей, получавших 0,5 мкг/кг ОА, рыбоводческие показатели достоверно $(\mathrm{p}<0,05)$ снижались к окончанию 2-месячного эксперимента (47). У молоди радужной форели (начальная масса 1,0 г) при 16-недельном наблюдении происходило явное замедление роста и эффективности использования корма, содержащего Т-2 в концентрациях от 1,0 мг/кг и выше (48). При потреблении корма, контаминированного ДОН в количестве от 1,0 до 12,9 мг/кг, в течение 8 нед замедлялись как рост, так и эффективность кормления, причем без клинических признаков интоксикации и с сохранением выживаемости, тогда как при увеличении содержания ДОН до 20 мг/кг происходил отказ от корма (49). Позже эффект снижения потребления корма для радужной форели с начальной массой 24 г был подтвержден после 8 нед использования корма с ДОН в количестве от 0,3 до 2,6 мг/кг $(50,51)$. Другие исследователи при скармливании 2 мг/кг ДОН негативный эффект у этой рыбы наблюдали раныше - через 23 и 32 сут $(52,53)$.

Продуктивность атлантического лосося (Salmo salar) снижалась после 15 нед употребления 3,7 мг/кг ДОН (54). В 8-недельном эксперименте на годовалых особях (начальная масса 58 г) содержание в корме 5,5 мг/кг ДОН привело к снижению средней массы рыб в опытной группе до 80,2 г в сравнении с 123,2 г в контрольной (55). В аналогичном по продолжительности эксперименте на смолтах с внесением в корм 0,5-6,0 мг/кг чистого препарата ДОН эффективность кормления, масса, длина тела рыб и фактор кондиции обратно коррелировали с дозой токсина (56).

У всех перечисленных видов рыб - карпа обыкновенного, канального сома, нильской тиляпии, радужной форели, атлантического лосося продолжительное потребление контаминированных комбикормов сопровождалось изменениями биохимических показателей крови, активности 
пищеварительных, антиокислительных и трансформирующих ферментов, патологическими нарушениями органов и функциональных систем, а также снижением устойчивости к инфекционным заболеваниям.

Так, у карпа обыкновенного за 4 нед потребления 5,3 мг/кг Т-2 наблюдалось изменение количества гемоглобина, признаки анемии и лейкопении, значительное возрастание концентрации глюкозы в плазме и активности аланинаминотрансфераз, а также существенное снижение концентрации триглицеридов и активности церулоплазмина (36). При 4-недельном скармливании годовалому карпу 4,11 мг/кг Т-2 наряду с НТ-2 в меньшем количестве не было выявлено существенных различий с контролем по маркерам липидного окисления, но снижалась активность глутатионовой редокс-системы и глутатион-S-трансфераз (35). По мнению авторов, различия в активности трансформирующих и антиоксислительных ферментов объяснялись продолжительным воздействием токсина на организм. Ранее в 3-суточном эксперименте под действием Т-2 у карпа отмечали некоторое увеличение активности глутатион-S-трансфераз в гепатопанкреасе (57). При использовании Т-2 в количествах 0,52 и 2,45 мг/кг в течение 7 и 28 сут увеличивалась активность как глутатион-S-трансфераз, так и глутатионпероксидаз, при этом экспрессия генов-паралогов gpx4 изменялась во времени, хоть и неодинаково: у gpx $4 a$ достоверно (p < 0,05) возрастала на 21-е сут и снижалась на 28-е сут, тогда как у gpx $4 b$ была увеличена и на 21-е, и на 28-е сут наблюдений (58).

У сеголеток карпа, выращиваемых в аквариумах на комбикорме с естественной контаминацией 1,25 мг/кг ДОН, через 30 сут было установлено снижение в сыворотке крови содержания белка, триацилглицеролов, липопротеинов, холестерина, уменьшение активность аспартатаминотрансферазы и щелочной фосфатазы, резкое снижение количества $\beta$-липопротеинов и увеличение содержания глюкозы, а также нарушение функции гепатопанкреаса. У двухлеток карпа при выполнении опыта в садках с использованием того же контаминированного корма через 2,5 мес была увеличена активность трансфераз и щелочной фосфатазы, трипсина и амилазы, снижено содержание белка за счет $\beta$ - и $\gamma$-глобулиновой фракций, нарушены функции гепатоцитов и клеток поджелудочной железы, регуляция секреции, повреждена почечная ткань, понижена жизнестойкость, атрофирована слизистая кишечника (37). Скармливание годовалому карпу в течение 4 нед ДОН с примесью его природного аналога 15-ацетил-ДОН показало, что при контаминации 5,96 мг/кг окисление липидов и активность глутатионтрансферазы в гепатопанкреасе соответствуют контролю, а концентрация восстановленной формы глутатиона достоверно (p < 0,05) возрастает к концу эксперимента (на 28-е сут). Продолжительность воздействия ДОН заметно влияла на экспрессию генов gpx4, которая для gpx $4 a$ превышала контроль на 21-е и 28-е сут, а для gpx4b- на протяжении всего периода наблюдения (58). Полученные результаты позволили авторам сделать общий вывод о том, что продолжительность потребления Т-2 и ДОН влияет на экспрессию паралогов gpx4 при неизменной активности глутатионпероксидаз (58).

Регулярное потребление ФУМ В в дозах 0,5 и 5,0 мг/кг годовалыми карпами в течение 42 сут наряду со снижением массы рыб сопровождалось возрастанием числа эритроцитов и тромбоцитов, концентрации креатинина и общего билирубина в сыворотке крови и увеличением активности аспартатаминотрансферазы и аланинаминотрансферазы, что позволило считать почки и печень ключевыми органами повреждения этим токсином 
и предположить возможность нарушения мембраны эритроцитов или влияния на процесс дыхания (38). В группе карпов, получавших ФУМ В1 в дозе 5,0 мг/кг, возрастала частота поверхностного эритродерматита, вызванного Aeromonas salmonicida subsp. nova (38). От корма, контаминированного 10 и 100 мг/кг ФУМ В1, у рыб того же возраста через 42 сут наблюдали гистологические изменения кровеносных сосудов, печени, почек, сердца и мозга, рассеянные повреждения экзокринной и эндокринной частей гепатопанкреаса и межпочечной ткани, вероятно, из-за ишемии и/или повышенной эндотелиальной проницаемости (39), при обследовании мозга были выявлены глубокие повреждения нейронов (59).

После 6-недельного скармливания молоди канального сома 1,0 и 2,0 мг/кг Т-2 смертность в группах, инфицированных вирулентным изолятом Edwardsiella ictaluri, через 21 сут была значительно больше, чем в контрольных (60). Рацион с ДОН-контаминированной кукурузой также повышал восприимчивость к этому возбудителю (61). У взрослых особей, содержащихся 5 нед на кормах с ФУМ В1 из культуры гриба в количествах 35 , 62, 170 и 313 мг/кг, при гистологических исследованиях не было обнаружено явных повреждений мозга, сердца, печени, селезенки, жабер, головной и стержневой почек, желудка, кишечника, кожи и половых желез, позволивших считать, что при доращивании этот вид может переносить контаминацию до 313 мг/кг без негативных последствий (62). Тем не менее 10недельное потребление ФУМ В1 в количествах 80 мг/кг и более в группе годовалых сомов приводило к снижению гематокрита, числа лейкоцитов и эритороцитов, а в группе 2-летних особей 14-недельное потребление 320 мг/кг ФУМ В 1 - к снижению гематокрита и эритропении при лейкоцитозе (42). В печени у 1- и 2-летних сомов, которым в течение 10 и 14 нед скармливали 20 мг/кг и более ФУМ В1, наблюдали очаги гиперплазии субкапсулярных жировых клеток, набухшие гепатоциты с вакуолями, наполненными липидами, инфильтрацию лимфоцитов и разрозненные некротические гепатоциты (42). У молоди рыб с начальной массой 6,1 г, получавшей 80 и 240 мг/кг ФУМ В1 в течение 12 нед, был значительно снижен гематокрит, а при концентрациях 40, 80 и 120 мг/кг ФУМ В1 наблюдали накопление гликогена в печени, вакуолизацию нервных волокон и увеличение периваскулярного лимфогистиоцитарного слоя в мозге (43). У 2-летних сомов при 12-недельном скармливании рациона с добавлением 10 мг/кг и выше ФУМ В1 в виде культуры гриба отмечали значительный рост соотношения свободного сфингамина и свободного сфингозина в сыворотке, печени, почках и мышцах, но не в мозге (63). У 2-летних особей, содержащихся на кормах с 20 и 80 мг/кг ФУМ В1 из культуры гриба-продуцента, после 14 нед была снижена устойчивость к инфекции Edwardsiella ictaluri и наблюдалось более слабое образование антител в сравнении с контрольной группой (44).

У молоди нильской тиляпии с начальной массой 2,7 г при 8-недельном скармливании рациона, содержащего 150 мг/кг ФУМ В1 из культуры гриба, гематокрит был значительно снижен, а соотношение свободного сфингамина и свободного сфингозина в печени увеличено (46).

В опытах на радужной форели (начальная масса 24 г) при 8-недельном скармливании 2,6 мг/кг ДОН наблюдали морфологические нарушения в печени в виде субкапсульных геморрагий, отека, изменений гепатоцитов и жировой инфильтрации (51). У годовалой радужной форели, потреблявшей 2,0 мг/кг ДОН в течение 23 сут, достоверно $(\mathrm{p}<0,05)$ снижались средняя концентрация гемоглобина в эритроците и биохимические показатели, а при гистологических исследованиях у 9 из 10 рыб была выявлена 
дегенерация эпителиальных клеток извитых канальцев почек (64) и у нескольких особей отмечались геморрагии в печени, описанные ранее J.M. Hooft с соавт. (50). При использовании корма, содержащего 2,0 мг/кг ДОН, через 23 и 32 сут наблюдали изменения активности глутатионпероксидазы в почках, глутатионредуктазы в жабрах и почках, каталазы в почках и печени, глутатионтрансферазы в жабрах и печени, указывающие на то, что ДОН индуцировал окислительный стресс, но практически не влиял на окисление липидов (65). Позже было подтверждено влияние ДОН на регуляцию экспрессии ключевых генов и основные метаболические процессы у этих рыб $(52,53)$.

При 8-недельном кормлении смолтов атлантического лосося на рационах с ДОН в количествах от 0,5 до 6,0 мг/кг клинические биохимические параметры и ответ на вакцинацию Aeromonas salmonicida обратно коррелировали с дозой токсина (56).

Все эти эксперименты позволили получить важную информацию о влиянии Т-2, ДОН и ФУМ В1 на продуктивность, состояние внутренних органов рыбы через изменение биохимических показателей и активности ферментов в печени, почках, жабрах, а также восприимчивости к инфекциям при искусственном заражении, чем создали основу для перехода к следующему этапу - уточнению порогов безопасного потребления и расшифровке механизмов токсического действия с введением индивидуальных препаратов микотоксинов в рацион без растительных ингредиентов. Это позволило корректно наблюдать действие выбранного токсиканта на фоне полноценного, сбалансированного по питательным веществам корма, не содержащего других контаминантов микогенной природы. Для двух фузариотоксинов - ДОН и ЗЕН были получены новые сведения о повреждениях на молекулярном уровне и установлены особенности ответных реакций врожденного иммунитета карповых рыб с участием факторов, провоцирующих и препятствующих развитию воспалительных процессов.

На молодых особях карпа 12-16 см в длину в серии 6-недельных опытов было изучено действие доз 0,352, 0,619 и 0,953 мг/кг ДОН, которые не влияли на продуктивность. При наименьшей дозе токсина число лейкоцитов в крови у рыб было снижено, а активность антиоксидантных ферментов супероксиддисмутазы и каталазы в эритроцитах увеличена, что указывало на иммунодепрессивный эффект ДОН (66). Под действием ДОН в наибольшей концентрации возрастало окисление липидов в печени, головной почке и селезенке, происходило накопление жира в теле рыбы, при этом изменения активности лактатдегидрогеназы в почках и мышцах и накопление лактата в сыворотке крови указывали на влияние ДОН на анаэробный метаболизм, а снижение сывороточного альбумина при средней и высокой дозах - на его риботоксическое действие (67). Далее на особях длиной 9-12 см была изучена динамика повреждений печени и изменений активности ее ферментов, а также иммунного ответа при скармливании 0,953 мг/кг ДОН в течение 7, 14, 26 и 56 сут. Первые 2 нед сопровождались угнетением биотрансформирующих ферментов, а после активацией аланинаминотрансферазы, что указывало на повреждение ткани печени: через 14 и 26 сут на гистологических срезах ткани обнаруживали агрегацию липидов, вакуолизацию и гиперемию на фоне угнетения ферментов, участвующих в глутатионовом цикле и снижении окислительного стресса (68). В первые 2 нед поступление ДОН приводило к активации ферментов и цитокинов как препятствующих, так и способствующих развитию воспалительного процесса, а продолжение воздействия вызывало активацию аргиназ до наибольших значений в лейкоцитах головной почки через 26 сут (69). 
Несмотря на некоторые иммуномодулирующие эффекты в начале эксперимента, авторы пришли к выводу о том, что ДОН оказывает системное иммунодепрессивное действие на карпа (69).

У молодых особей карпа длиной 12-16 см в течение 4-недельного скармливания 0,332, 0,621 и 0,797 мг/кг ЗЕН не наблюдали снижения роста и свойственного другим видам рыб эстрогенного эффекта, измеряемого по концентрации вителлогенина в сыворотке, но при этом гематологические параметры претерпевали значительные смещения. Было показано влияние средней и высокой доз микотоксина на число лейкоцитов, гранулоцитов и моноцитов и подтверждена генотоксичность ЗЕН по образованию микроядер в эритроцитах (70). Кроме того, было установлено действие ЗЕН на метаболизм углеводов, окисление липидов в органах и метаболизм кислорода, что указывало на его способность увеличивать общую метаболическую нагрузку (71). Сравнительное изучение лейкоцитов, выделенных из головной и туловищной почек, на способность накапливать окись азота, в биопробе на респираторную активность, хемилюминесцентном тесте и по активности аргиназ показало, что хотя при низких концентрациях ЗЕН происходит усиление иммунных реакций, при более высоких наблюдается их отчетливая депрессия (72). В печени все испытанные концентрации ЗЕН приводили к снижению экспрессии генов, регулирующих иммунный ответ, антиоксидантную систему и чувствительность к эстрогенам, а также к значительному возрастанию экспрессии Н+-аденозинтрифосфатазы вакуолярного типа, что согласовывалось с ранее установленной связью между ЗЕН и лизосомальными функциями (73). Эти исследования подтвердили влияние ЗЕН на многие важнейшие жизненные процессы в организме карпа и показали, что допустимые уровни содержания, ранее введенные для комбикормов, слишком высоки и не предотвращают его повреждающее действие.

В серии работ китайских исследователей с другим представителем карповых - белым амуром (Ctenopharyngodon idella) также было изучено влияние ДОН (74-76). При кормлении молоди с начальной массой около 12 г в течение 60 сут комбикормами с ДОН в количествах 0,318, 0,636, 0,922, 1,243 и 1,515 мг/кг впервые показано, что этот токсин способен вызывать уродства рыбы и приводить к гистопатологическим изменениям, окислительному повреждению, снижению антиоксидантной способности, апоптозу клеток и деструкции плотных контактов в кишечнике через сигнальные системы Nrf2, с-Jun N-терминальной киназы (с-Jun N-terminal kinases, JNK) и киназы легкой цепи миозина (myosin light-chain kinase, MLCK). По совокупности измеренных показателей безопасной названа доза ДОН 0,318 мг/кг (74). Продолжение исследований показало, что ДОН нарушает иммунную функцию кишечника по механизмам, частично связанным с двумя сигнальными путями - ядерного фактора каппа B (nuclear factor kappa B, NF-kB) и мишени рапамицина (target of rapamicin, TOR). C учетом данных по заболеваемости энтеритом, вызванным Aeromonas hydrophila, активности лизоцима и кислой фосфатазы, а также по содержанию $\operatorname{Ig}$ в в проксимальном отделе кишечника рекомендуемая доза ДОН составила 0,2520,310 мг/кг (75). В жабрах у этих рыб в тех же экспериментальных условиях введение в корм ДОН в количествах более 0,318 мг/кг также приводило к гистопатологическим изменениям, окислительному повреждению, снижению антиоксидантной способности, апоптозу клеток и деструкции плотных контактов, что происходило предположительно с участием сигнальных систем Nrf2, JNK и MLCK и без влияния на экспрессию генов Keap $1 b$, claudin-b, claudin-3c и claudin-15b. По активности малонового 
диальдегида и суммы антиоксидантов были рассчитаны допустимые количества ДОН - 0,376 и 0,413 мг/кг (76).

При кормлении белого амура кормом с 0,535, 1,041, 1,548, 2,002 и 2,507 мг/кг ЗЕН наблюдались окислительное повреждение, апоптоз и нарушение структурной целостности кишечника рыбы, которые, по предположению авторов, связаны с сигнальными путями Nrf2, протеинкиназ, активированных p38 митогеном (p38MAPK), и MLCK. При этом не было изменений со стороны антиоксидантных генов Keap $1 b$, глутатион-S-трансфераз ( GSTP1, GSTP2), а также отвечающих за целостность структуры кишечника occludin, claudin-c и claudin-3c (77).

Следует отметить весьма успешный опыт использования аквариумных рыб в качестве модельных организмов для оценки хронического действия микотоксинов на карповых рыб. Так, при включении в корма Danio rerio 0,1-3 мг/кг ДОН выявлено повышение генетических биомаркеров печени и влияние на репродуктивную систему (78). По наблюдениям за содержанием вителлогенина и молекулярного биомаркера vitellogenin-1 mRNA (vtg-1) на взрослых особях D. rerio удалось установить, что, кроме прямых эстрогенных эффектов, ЗЕН способен влиять и на другие пути онтогенеза $(79,80)$.

Значительный прогресс достигнут и в изучении токсикозов рыб высокого трофического уровня. Так, при скармливании молоди радужной форели кормов, содержащих 1,0 и 1,8 мг/кг Т-2, в течение 24 сут, несмотря на отсутствие гистологических изменений, диагностируется отчетливый окислительный стресс, который влияет на детоксицирующую систему и может приводить к повышению чувствительности этой рыбы к другим стрессовым факторам (81). У годовалых особей за 23 сут на кормах с 2 мг/кг ДОН было выявлено повышение в головной почке содержания цитокинов TNF- $\alpha$ и IL-8, провоцирующих воспалительные процессы (82).

Для ЗЕН подтверждена способность связываться с эстрогеными рецепторами и вызывать экспрессию соответствующих генов у радужной форели (83). Наблюдения через 24, 72 и 168 ч после однократного внутрибрюшинного введения 10 мг/кг ЗЕН молоди с начальной массой 55 г не выявили признаков повреждения печени, поскольку активность аланининаминотрансферазы, аспарагинаминотрансферазы и содержание глюкозы в плазме крови не изменялись, однако при этом значительно снижалось содержание железа в печени и яичниках, что, по мнению авторов, могло быть как следствием, так и причиной окислительного стресса (84). Согласно результатам 8-недельного эксперимента на 12-месячных особях атлантического лосося с начальной массой 58 г препарат ДОН в дозе 5,5 мг/кг нарушал кишечную интеграцию в среднем и дистальном отделах, что проявлялось в снижении экспрессии маркеров барьерных белков (claudin 25b, occludin, tricellulin) и возрастании экспрессии маркера ядерного антигена пролиферирующих клеток, при этом в дистальном отделе кишечника относительная экспрессия маркеров двух супрессоров сигнального пути цитокинов SOCS1 и SOCS2 возрастала. Однако, по мнению авторов, несмотря на то что повреждающее воздействие смягчалось супрессорами передачи сигналов цитокинам, такую дисфункцию кишечного барьера не следует недооценивать (55). В эксперименте той же продолжительности на смолтах атлантического лосося с внесением в корма от 0,5 до 6 мг/кг ДОН было установлено, что относительная масса органов возрастала с дозой токсина, а максимальное количество токсина, не вызывающее обнаруживаемого вредного воздействия (no-observed adverse effect level, NOAEL), coставляло 1 мг/кг (56). 
К сожалению, до сих пор проблема интоксикаций рыб, связанных с присутствием в кормах ОА, изучена крайне недостаточно. Известно, что у молоди канального сома на рационах с 8 мг/кг ОА, внесенным в виде культурального материала Aspergillus ochraceus, гематокрит снижался, но число лейкоцитов крови не изменялось (45). Смертность в опытных группах, потреблявших 4 мг/кг ОА в течение 6 нед, а затем инфицированных вирулентным изолятом Edwardsiella ictalurid, через 21 сут была значительно выше, чем в контрольных (60). Установлено, что некроз почечных канальцев у сомов не наблюдался, но в рыхлой соединительной ткани почек при дозах 4 и 8 мг/кг появлялись обширные мультифокальные меланомакрофагальные центры. Самым заметным гистопатологическим поражением при содержании ОА 1 мг/кг и более был некроз гепатопанкреатических тканей, особенно экзокринных клеток поджелудочной железы, окружающих воротные вены, и эта патология в итоге приводила к облитерации нормальной ткани поджелудочной железы (41). При контаминации пяти рационов для смолтов атлантического лосося чистым препаратом ОА в дозах 0,2-2,4 мг/кг через 8 нед показатели продуктивности оставались без изменений, хотя после первых 3 нед прослеживалась тенденция к увеличению некоторых клинических биохимических параметров и усиление экспрессии двух иммунных маркеров в селезенке, при этом рассчитать NOAEL по доступному диапазону концентраций не удалось (56).

Данные о характере токсико-биологического действия циклопиазоновой кислоты весьма ограничены. У молоди канального сома (начальная масса 7,5 г), получавшей в течение 10 нед корм с внесенным токсином в количестве 10 мг/кг, наблюдались гистологические поражения в почках и желудке (накопление белковых гранул в эпителии почечных канальцев и некроз желудочных желез), однако поражений печени и влияния на гематокрит, концентрацию гемоглобина, число лейкоцитов и эритроцитов выявлено не было (33). Ситуация в отношении цитринина, микофеноловой кислоты, альтернариола и эмодина остается неизученной.

В литературе отсутствуют сведения о влиянии микотоксинов рассматриваемой группы на толстолобика белого (Hypophthalmichthys molitrix), толстолобика пестрого (Hypophthalmichthys nobilis), линя (Tinca tinca), пелядь (Coregonus peled), веслоноса (Polyodon spathula), карасей серебряного (Carassius auratus) и золотого (C. carassius), угря (Anquila spp.), осетра сибирского (Acipenser baerii), бестера (Huso huso $\times$ Acipenser ruthenus), составляющих базу российского рыбоводства. В связи с этим в перспективные исследовательские проекты желательно поэтапно включать виды, наиболее востребованные в отрасли, и своевременно предусматривать для них развернутую оценку по всему набору ожидаемых токсикантов. Кроме того, расширение ассортимента выращиваемой рыбы с учетом успешного опыта других стран диктует необходимость внимательного сбора, обобщения и анализа вновь появляющейся информации. Как весьма интересные следует отметить работы, в которых показана высокая чувствительность к ОА лаврака обыкновенного (сибаса) (Dicentrarchus labrax L.) из семейства Мороновые (Moronidae) с LD50, равной 0,277 мг/кг массы (85), а также описано хроническое действие рационов, контаминированных ФУМ В1, на молодь африканского клариевого сома (Clarias gariepinus) $(86,87)$ и поликонтаминированного корма, содержащего наряду с ДОН другие фузариотоксины и альтернариол, на красную тиляпию (Oreochromis niloticus $\times$ O. mossambicus) (88). Заслуживает отдельного рассмотрения и характер действия токсина, нередко сопутствующего ФУМ В1 в фузариозном зерне кукурузы, - 
монилиформина, присутствие которого в кормах в виде культуры продуцентов $F$. moniliforme и $F$. proliferatum приводило к отчетливым смещениям гематологических и гистологических показателей у канального сома (89) и нильской тиляпии $(46,90)$.

По общему мнению, тема выявления микотоксинов в кормах для водных организмов и оценки последствий их негативного действия должна оставаться в центре внимания, особенно в связи с общей тенденцией замены дорогостоящих источников белка животного происхождения, таких как рыбная мука, более дешевыми, содержащими растительный белок. В новых рецептах, кроме вышеуказанных ингредиентов, упоминаются такие виды комбикормового сырья, как глютены (побочные продукты переработки зерна на крахмал и патоку) и сухая зерновая барда с гидролизатами (91), для которых известна множественная контаминация микотоксинами (92). Рекомендовано расширенное применение в составе зерновой части комбикормов зерна сорго (93), хотя сравнительный анализ рисков, связанных с этим сырьем, не проводился. Из добавок с меньшей долей ввода, которые также могут быть источниками микотоксинов, следует отметить льняной, тыквенный жмыхи $(94,95)$, хлопковый шрот, водорослевую и травяную муку. Специальные обследования шротов еще только предстоят, но для трав и морских водорослей, предназначенных на переработку в кормовую муку, возможность множественной контаминации микотоксинами уже установлена $(96,97)$.

Рыбная мука и ее заменители, которые служат основным источником белка в рационах для лососевых рыб (98), в процессе транспортировки, хранения и использования могут легко подвергаться инфицированию микроскопическими грибами. Недавно в составе микобиоты рыбной, мясокостной и костной муки выявлены 11 потенциально токсигенных видов грибов Penicillium (99), однако мониторинг контаминации производственных партий микотоксинами не проводился. В связи с перспективными планами перевода отрасли аквакультуры на отечественную кормовую базу (100) необходимо начать координированные регулярные обследования производственных партий муки животного происхождения.

Все усилия по оценке реальной загрязненности кормов и сбору данных о повреждающем действии микотоксинов на организм рыб имеют целью введение норм их допустимого содержания. Однако обоснованные предложения по регламентации микотоксинов пока крайне немногочисленны: по Т-2 - для карпа обыкновенного (31), по ДОН - для белого амура (74-76) и атлантического лосося (56), по ФУМ В 1 - для канального сома $(42,43)$. Другой важный момент в системе мер по профилактике микотоксикозов в аквакультуре - обеспечение безопасности рыбной продукции для потребителей. В целом данные о трансформации микотоксинов в организме рыб и их сохранности в органах и мышечной ткани указывают на слабо выраженную или умеренную кумуляцию и медленное выведение, что объясняется физиологическими особенностями пойкилотермных организмов (54, 101-103). Объем таких сведений пока ограничен и, вероятно, поэтому регламенты по остаточным количествам микотоксинов в продукции до сих пор не приняты. Однако поиск новых информативных подходов к корректной оценке рисков воздействия микотоксинов на рыбу и их трансмиссии в продукцию продолжается, и решение, несмотря на сложность ситуации, наверняка будет найдено.

В России вступивший в силу в сентябре 2017 года Технический регламент Евразийского экономического союза (ЕАЭС) «О безопасности 
рыбы и рыбной продукции» (104) определяет максимально допустимые количества остатков ветеринарных терапевтических препаратов и стимуляторов роста, разрешенных к использованию в аквакультуре. Введение микотоксинов как конгенеров в ближайшем будущем вряд ли произойдет, поскольку блок необходимой информации пока не сформирован. Первым шагом на пути решения этой проблемы должны стать систематические регулярные мониторинговые обследования комбикормовой продукции, выпуск которой организован во всех федеральных округах страны. Обобщение полученных данных позволит обоснованно подойти к организации проектов, направленных на изучение трансмиссии, метаболизма, аккумуляции значимых микотоксинов у видов, которые составляют основу интенсивного рыбоводства, и далее определить приоритетные критерии регламентации остаточных содержаний в кормах и продукции. Для сырья и готовой комбикормовой продукции в нашей стране введены обязательные требования на соответствие нормативам по показателям качества и безопасности (ГОСТ 10385-2014 «Комбикорма для рыб. Общие технические условия». М., 2014) и создана современная методическая база для проведения микотоксикологического контроля (ГОСТ 31653-2012 «Корма. Метод иммуноферментного определения микотоксинов». М., 2012; ГОСТ 31691-2012 «Зерно и продукты его переработки, комбикорма. Определение содержания зеараленона методом высокоэффективной жидкостной хроматографии». М., 2012; ГОСТ 32587-2013 «Зерно и продукты его переработки, комбикорма. Определение охратоксина А методом высокоэффективной жидкостной хроматографии». М., 2013; ГОСТ 34108-2017 «Корма, комбикорма, комбикормовое сырье. Определение содержания микотоксинов прямым твердофазным конкурентным иммуноферментным методом». М., 2017; ГОСТ Р 51116-2017 «Комбикорма, зерно и продукты его переработки. Определение содержания дезоксиниваленола методом высокоэффективной жидкостной хроматографии». М., 2017).

Таким образом, к настоящему времени наука располагает убедительными доказательствами глубокого повреждающего действия микотоксинов на непромысловых рыб при поступлении с контаминированными кормами. С практической точки зрения особую ценность имеет обширный блок информации по пороговым содержаниям, при которых риск развития алиментарных токсикозов может быть существенно снижен. Значительный научный интерес представляют данные по смещению биохимических показателей крови, активности пищеварительных, антиокислительных и трансформирующих ферментов, а также по изменению восприимчивости рыб к инфекциям. За последние годы выполнены первые исследования молекулярных механизмов, приводящих к нарушениям детоксицирующей, иммунной и репродуктивной функций у рыб и предложены оригинальные методологические приемы для оценки доз допустимого потребления этих токсикантов. Однако в дальнейшем при планировании экспериментальных работ крайне важно учитывать аспекты, необходимые для более точного понимания реальных ситуаций, в частности предусматривать варианты с сочетанием двух и более микотоксинов, а также проводить оценку их комбинаций в разных концентрациях. Развитие такого подхода и своевременная систематизация всего объема накопленных сведений позволит создать в нашей стране научно обоснованную эффективную систему контроля безопасности кормов и обеспечить устойчивое ветеринарное благополучие в рыбоводческой отрасли. 


\section{Л ИТ Е РАТ У РА}

1. The state of world fisheries and aquaculture. Food and Agriculture Organization of the United Nations, Rome, 2018.

2. Bostock J., McAndrew B., Richards R., Jauncey K., Telfer T., Lorenzen K., Little D.C., Ross L., Handisyde N., Gatward I., Corner R. Aquaculture: global status and trends. Proceedings of the Royal Society B: Biological Sciences, 2010, 365(1554): 2897-2912 (doi: 10.1098/rstb.2010.0170).

3. Wolf H., Jackson E.W. Hepatomas in rainbow trout: descriptive and experimental epidemiology. Science, 1963, 142(3593): 676-678 (doi: 10.1126/science.142.3593.676-a).

4. Hintikka E.L. Trichothecene poisoning on fish. In: Fusarium: mycotoxins, taxonomy and pathogenicity /J. Chełkowski (ed.). Elsevier Science Publishers B.V., Amsterdam, 1989: 131-138.

5. Vanyi A., Buza L., Széka A. Fusariotoxicosis. IV. The effect of F-2 toxin (zearalenone) on the spermiogenesis of the carp. Hungarian Veterinary Journal, 1974, 29: 457-461.

6. Abdelhamid A.M. Effect of Sterigmatocystin contaminated diets on fish performance. Archives of Animal Nutrition, 1988, 38(9): 833-846 (doi: 10.1080/17450398809430911).

7. Barbosa B.T.S., Pereyra C.M., Soleiro C.A., Dias E.O., Oliveira A.A., Keller K.A., Silva P.P.O., Cavaglieri L.R., Rosa C.A.R. Mycobiota and mycotoxins present in finished fish feeds from farms in the Rio de Janeiro State, Brazil. International Aquatic Research, 2013, 5(1): 3 (doi: 10.1186/2008-6970-5-3).

8. Greco M., Pardo A., Pose G. Mycotoxigenic fungi and natural co-occurrence of mycotoxins in rainbow trout (Oncorhynchus mykiss) feeds. Toxins, 2015, 7(11): 4595-4609 (doi: 10.3390/toxins7114595).

9. Pinotti L., Ottoboni M., Giromini C., Dell'Orto V., Cheli F. Mycotoxin contamination in the EU feed supply chain: a focus on cereal byproducts. Toxins, 2016, 8(2): 45 (doi: 10.3390/toxins8020045).

10. Pietsch C., Kersten S., Burkhardt-Holm P., Valenta H., Dänicke S. Occurrence of deoxynivalenol and zearalenone in commercial fish feed: an initial study. Toxins, 2013, 5(1): 184-192 (doi: 10.3390/toxins5010184).

11. Matejova I., Svobodova Z., Vakula J., Mares J., Modra H. Impact of mycotoxins on aquaculture fish species: a review. Journal of the World Aquaculture Society, 2017, 48(2): 186-200 (doi: 10.1111/jwas. 12371).

12. Pietsch C. Risk assessment for mycotoxin contamination in fish feeds in Europe. Mycotoxin Research, 2020, 36(1): 41-62 (doi: 10.1007/s12550-019-00368-6).

13. Стратегия развития аквакультуры в Российской Федерации на период до 2020 года (утв. Минсельхозом РФ 10.09.2007. Режим доступа: https://normativ.kontur.ru/document?moduleId=1\&documentId=151849. Без даты.

14. Желтов Ю.А. Рецепты комбикормов для выращивания рыб разных видов и возрастов в промышленном рыбоводстве. Киев, 2006.

15. Скляров В.Я. Корма и кормление рыб в аквакультуре. М., 2008.

16. Остроумова И.Н. Биологические основы кормления рыб. СПб, 2012.

17. Гамыгин Е.А., Багров А.М., Бородин А.Л., Ридигер А.В. Расширение сырьевой базы кормопроизводства для рыб. Рыбное хозяйство, 2013, 4: 87-88.

18. Бурлаченко И.В. Актуальные вопросы безопасности комбикормов в аквакультуре рыб. М., 2008.

19. Смирнова И.Р., Михалев А.В., Сатюкова Л.П., Борисова В.С. Ветеринарно-санитарная характеристика основных видов кормов для прудовых рыб. Ветеринария, 2009, 5: 30-36.

20. Наумова А.М., Розумная Л.А., Наумова А.Ю., Логинов Л.С. Повышение качества рыбных комбикормов: эколого-технологические и ветеринарно-санитарные аспекты. Российский журнал «Проблемы ветеринарной санитарии, гигиены и экологии», 2019, 4(32): 474-481.

21. Кононенко Г.П., Буркин А.А. Фузариотоксины в зерновых кормах. Ветеринарная патология, 2002, 2: 128-132.

22. Кононенко Г.П., Буркин А.А. Контаминация фузариотоксинами зерна кукурузы и риса на основных регионах возделывания культур в Российской Федерации. Сельскохозяйственная биология, 2008, 5: 88-91.

23. Кононенко Г.П., Буркин А.А. О контаминации фузариотоксинами зерна злаков, используемых на кормовые цели. Сельскохозяйственная биология, 2009, 4: 81-88.

24. Kononenko G.P., Burkin A.A., Zotova E.V., Ustyuzhanina M.I., Smirnov A.M. Features of wheat and barley grain contamination with fusariotoxins. Russian Agricultural Sciences, 2018, 44(2): $137-$ 141 (doi: 10.3103/S106836741802009X).

25. Кононенко Г.П., Буркин А.А., Зотова Е.В., Смирнов А.М. Микотоксикологическое исследование кормового зерна кукурузы (1998-2018 гг.). Российская сельскохозяйственная наука, 2019, (3): 28-31 (doi: 10.31857/S2500-26272019328-31).

26. Кононенко Г.П., Буркин А.А., Зотова Е.В., Соболева Н.А. Охратоксин А: исследование контаминации зерна. Прикладная биохимия и микробиология, 2000, 36(2): 209-213.

27. Kononenko G.P., Burkin A.A. A survey on the occurrence of citrinin in feeds and their ingredients in Russia. Mycotoxin Research, 2008, 24(1): 3-6 (doi: 10.1007/BF02985263). 
28. Kononenko G.P., Burkin A.A. Peculiarities of feed contamination with citrinin and ochratoxin A. Agricultural Sciences, 2013, 4(1): 34-38 (doi: 10.4236/as.2013.41006).

29. Кононенко Г.П., Устюжанина М.И., Буркин А.А. Проблема безопасного использования подсолнечника (Helianthus anпии L.) для пищевых и кормовых целей. Сельскохозяйственная биология, 2018, 53(3); 485-498 (doi: 10.15389/agrobiology.2018.3.485rus).

30. Santacroce M.P., Conversano M.C., Casalino E., Lai O., Zizzadoro C., Centoducati G., Crescenzo G. Aflatoxins in aquatic species: metabolism, toxicity and perspectives. Reviews in Fish Biology and Fisheries, 2008, 18(1): 99-130 (doi: 10.1007/s11160-007-9064-8).

31. Галаш В.Т. Токсико-биологическое действие трихотеценовых микотоксинов на карпа и предельно допустимая концентрация T-2-токсина в карповых комбикормах. Автореф. канд. дис. M., 1988.

32. Sahoo P.K., Mukherjee S.C., Mohanty S., Dey S., Nayak S.K. A preliminary study on acute citrinin toxicity in rohu (Labeo rohita) fingerlings. Indian Journal of Comparative Microbiology, Immunology and Infection Diseases, 1999, 20(1): 62-64.

33. Jantrarotai, W., Lovell R.T. Acute and subchronic toxicity of cyclopiazonic acid to channel catfish. Journal of Aquatic Animal Health, 1990, 2(4): 255-260 (doi: 10.1577/15488667(1990)002<0255:AASTOC>2.3.CO;2).

34. Doster R.C., Sinnhuber R.O., Wales J.H. Acute intraperitoneal toxicity of ochratoxins A and B in rainbow trout (Salmo gairdneri). Food and Cosmetic Toxicology, 1972, 10(1): 85-92 (doi: 10.1016/S0015-6264(72)80049-X).

35. Pelyhe C., Kövesti B., Zándoki E., Kovács B., Szabó-Fodor J., Mézes M., Balogh K. Effect of 4-week feeding of deoxynivalenol- or T-2-toxin-contaminated diet on lipid peroxidation and glutathione redox system in the hepatopancreas of common carp (Cyprinus carpio L.). Mycotoxin Research, 2016, 32: 77-83 (doi: 10.1007/s12550-016-0242-1).

36. Matejova I., Faldyna M., Modra H., Blahova J., Palikova M., Markova Z., Franc A., Vicenova M., Vojtek L., Bartonkova J., Sehonova P., Hostovsky M., Svobodova Z. Effect of T-2 toxincontaminated diet on common carp (Cyprinus carpio L.). Fish and Shellfish Immunology, 2017, 60: 458-465 (doi: 10.1016/j.fsi.2016.11.032).

37. Скляров В.Я., Студенцова Н.А., Селиванова В.А., Жердева Е.П. Влияние микотоксинов в кормах на рост и физиологическое состояние карпа. Известия ВУЗов. Пищевая технология, 1998, (5-6): 16-18.

38. Pepeljnjak S., Petrinec Z., Kovaci S., Segvic M. Screening toxicity study in young carp (Cyprinus carpio L.) on feed amended with fumonisin B1. Mycopathologia, 2002, 156(2): 139-145 (doi: 10.1023/a:1022944927493).

39. Petrinec Z., Pepeljnjak S., Kovaci S., Krznaric A. Fumonisin B1 causes multiple lesions in common carp (Cyprinus carpio). Deutsche Tierärztliche Wochenschrift, 2004, 111(9): 358-363.

40. Manning B.B., Li M.H., Robinson E.H., Gaunt P.S., Camus A.C., Rottinghaus G.E. Response of catfish to diets containing T-2 toxin. Journal of Aquatic Animal Health, 2003, 15(3): 230-239 (doi: 10.1577/H03-019).

41. Manning В. Микотоксикозы в рыбоводстве. В кн.: Микотоксины и микотоксикозы /Под ред. Д. Диаза. М., 2006: 275-292.

42. Lumlertdacha S., Lovell R.T., Shelby R.A., Lenz S.D., Kemppainen B.W. Growth, hematology, and histopathology of channel catfish, Ictalurus punctatus, fed toxins from Fusarium moniliforme. Aquaculture, 1995, 130(2-3): 201-218 (doi: 10.1016/0044-8486(94)00219-E).

43. Li M.H., Raverty S.A., Robinson E.H. Effects of dietary mycotoxins produced by the mould Fusarium moniliforme on channel catfish Ictalurus punctatus. Journal of the World Aquaculure. Society, 1994, 25(4): 512-516 (doi: 10.1111/j.1749-7345.1994.tb00820.x).

44. Lumlertdacha S., Lovell R.T. Fumonisin-contaminated dietary corn reduced survival and antibody production by channel catfish challenged with Edwardsiella ictaluri. Journal of Aquatic Animal Health, 1995, 7(1): 1-8 (doi: 10.1577/1548-8667(1995)007<0001:FCDCRS>2.3.CO;2).

45. Manning B.B., Ulloa R.M., Li M.H., Robinson E.H., Rottinghaus G.E. Ochratoxin A fed to channel catfish (Ictalurus pinctatus) causes reduced growth and lesions of hepatopancreatic tissue. Aquaculture, 2003, 219(1-4): 739-750 (doi: 10.1016/S0044-8486(03)00033-4).

46. Tuan N.A., Manning B.B., Lovell R.T., Rottinghaus G.E. Responses of Nile tilapia (Oreochromis niloticus) fed diets containing different concentrations of moniliformin and fumonisin B1. Aquaculture, 2003, 217(1-4): 515-528 (doi: 10.1016/S0044-8486(02)00268-5).

47. Diab A.M., Salem R.M., El-Keredy M.S., Abeer E.-K.M.S., Ali G.I.E., El-Habashi N. Experimental ochratoxicosis A in Nile tilapia and its amelioration by some feed additives. International Journal of Veterinary Science and Medicine, 2018, 6(2): 149-158 (doi: 10.1016/j.ijvsm.2018.09.004).

48. Poston H.A., Coffin J.L., Combs G.F. Jr. Biological effects of dietary T-2 toxin on rainbow trout, Salmo gairdneri. Aquatic Toxicology, 1982, 2(2): 79-88 (doi: 10.1016/0166-445X(82)90007-8).

49. Woodward B., Young L.G., Lun A.K. Vomitoxin in diets of rainbow trout (Salmo gairdneri). Aquaculture, 1983, 35: 93-101 (doi: 10.1016/0044-8486(83)90077-7).

50. Hooft J.M., Elmor A.E.H.I., Encarnaçго P., Bureau D.P. Rainbow trout (Oncorhynchus mykiss) is extremely sensitive to the feed-borne Fusarium mycotoxin deoxynivalenol (DON). Aquaculture, 
2011, 311(1-4): 224-232 (doi: 10.1016/j.aquaculture.2010.11.049).

51. Hooft J.M., Ferreira C., Lumsden J.S., Sulyok M., Krska R., Bureau D.P. The effects of naturally occurring or purified deoxynivalenol $(\mathrm{DON})$ on growth performance, nutrient utilization and histopathology of rainbow trout (Oncorhynchus mykiss). Aquaculture, 2019, 505: 319-332 (doi: 10.1016/j.aquaculture.2019.02.032).

52. Gonçalves R.A., Navarro-Guillén C., Gilannejad N., Dias J., Schatzmayr D., Bichl G., Czabany T., Moyano F.J., Rema P., Yúfera M., Mackenzie S., Martínez-Rodríguez G. Impact of deoxynivalenol on rainbow trout: Growth performance, digestibility, key gene expression regulation and metabolism. Aquaculture, 2018, 490: 362-372 (doi: 10.1016/j.aquaculture.2018.03.001).

53. Gonçalves R.A., Menanteau-Ledouble S., Schöller M., Eder A., Schmidt-Posthaus H., Mackenzie S., El-Matbouli M. Effects of deoxynivalenol exposure time and contamination levels on rainbow trout. Journal of the World Aquaculture Society, 2019, 50(1): 137-154 (doi: 10.1111/jwas. 12542).

54. Ananter A., Manyes L., Meca G., Ferrer E., Luciano F.B., Pimpão C.T., Font G. Mycotoxins and their consequences in aquaculture: A review. Aquaculture, 2016, 451: 1-10 (doi: 10.1016/j.aquaculture.2015.08.022).

55. Moldal T., Bernhoft A., Rosenlund G., Kaldhusdal M., Koppang E. Dietary deoxynivalenol (DON) may impair the epithelial barrier and modulate the cytokine signaling in the intestine of atlantic salmon (Salmo salar). Toxins, 2018, 10(9): 376 (doi: 10.3390/toxins10090376).

56. Bernhoft A., Høgåsen H.R., Rosenlund G., Moldal T., Grove S., Berntssen M.H.G., Thoresen S.I., Alexander J. Effects of dietary deoxynivalenol or ochratoxin A on performance and selected health indices in Atlantic salmon (Salmo salar). Food and Chemical Toxicology, 2018, 121: 374-386 (doi: 10.1016/j.fct.2018.08.079).

57. Kravchenko L.V., Galash V.T., Avren'eva L.T., Kranauskas A.E. On the sensitivity of carp, $C y$ prinus carpio, to mycotoxin T-2. Journal of Ichthyology, 1989, 29: 156-160.

58. Balogh K., Heincinger M., Fodor J., Mézes M. Effects of long term feeding of T-2 and HT-2 toxin contaminated diet on the glutathione redox status and lipid peroxidation processes in common carp (Cyprinus carpio L.). Acta Biologica Szegediensis, 2009, 53(Suppl. 1): 23-27.

59. Kovacić S., Pepeljnjak S., Petrinec Z., Klarić M.S. Fumonosin B1 neurotoxicity in young carp (Cyprinus carpio L.). Archives of Industrial Hygiene and Toxicology, 2009, 60(4): 419-426 (doi: 10.2478/10004-1254-60-2009-1974).

60. Manning B.B., Terhune J.S., Li M.H., Robinson E.H., Wise D.J., Rottinghaus G.E. Exposure to feedborne mycotoxins T-2 toxin and ochratoxin A causes increased mortality of channel catfish challenged with Edwardsiella ictaluri. Journal of Aquatic Animal Health, 2005, 17(2): 147-152 (doi: 10.1577/H03-063.1).

61. Manning B.B., Abbas H.A., Wise D.J., Greenway T. The effect of feeding diets containing deoxynivalenol contaminated corn on channel catfish (Ictalurus punctatus) challenged with Edwardsiella ictaluri. Aquaculture Research, 2014, 45(11): 1782-1786 (doi: 10.1111/are.12123).

62. Brown D.W., McCoy C.P., Rottinghaus G.E. Experimental feeding of Fusarium moniliforme culture material containing fumonosin B1 to channel catfish, Ictalurus punctatus. Journal of Veterinary Diagnostic Investigation, 1994, 6(1): 123-124 (doi: 10.1177/104063879400600128).

63. Goel S., Lenz S.D., Lumlertdacha S., Lovell R.T., Shelby R.A., Li M., Riley R.T., Kemppainen B.W. Sphingolipid levels in catfish consuming Fusarium moniliforme corn culture material containing fumonisins. Aquatic Toxicology, 1994, 30(4): 285-294 (doi: 10.1016/0166445X(94)00050-6).

64. Matejova I., Modra H., Blahova J., Franc A., Fictum P., Sevcikova M., Svobodova Z. The effect of mycotoxin deoxynivalenol on haematological and biochemical indicators and histopathological changes in rainbow trout (Oncorhynchus mykiss). BioMed Research International, 2014: 310680 (doi: $10.1155 / 2014 / 310680)$.

65. Šišperová E., Modrá H., Ziková A., Kloas W., Blahová J., Matejová I., Živná D., Svobodová Z. The effect of mycotoxin deoxynivalenol (DON) on the oxidative stress markers in rainbow trout (Oncorhynchus mykiss, Walbaum 1792). Journal of Applied Ichthyology, 2015, 31(5): 855-861 (doi: 10.1111/jai.12809).

66. Pietsch C., Kersten S., Valenta H., Dänicke S., Schulz C., Kloas W., Burkhardt-Holm P. In vivo effects of deoxynivalenol (DON) on innate immune responses of carp (Cyprinus carpio L.). Food and Chemical Toxicology, 2014, 68: 44-52 (doi: 10.1016/j.fct.2014.03.012).

67. Pietsch C., Schulz C., Rovira P., Kloas W., Burkhardt-Holm P. Organ damage and hepatic lipids accumulation in carp (Cyprinus carpio L.) after feed-borne exposure to the mycotoxin, deoxynivalenol (DON). Toxins, 2014, 6: 756-778 (doi: 10.3390/toxins6020756).

68. Pietsch C., Burkhardt-Holm P. Feed-borne exposure to deoxynivalenol leads to acute and chronic effects on liver enzymes and histology in carp. World Mycotoxin Journal, 2015, 8(5): 619-627 (doi: 10.3920/WMJ2015.1879).

69. Pietsch C., Katzenback B.A., Garcia-Garcia E., Schulz C., Belosevic M., Burkhardt-Holm P. Acute and subchronic effects on immune responses of carp (Cyprinus carpio L.) after exposure to deoxynivalenol (DON) in feed. Mycotoxin Research, 2015, 31: 151-164 (doi: 10.1007/s12550-0150226-6). 
70. Pietsch C., Kersten S., Valenta H., Dänicke S., Schulz C., Burkhardt-Holm P., Junge R. Effects of dietary exposure to zearalenone (ZEN) on carp (Cyprinus carpio L.). Toxicon, 2015, 7(9): 34653480 (doi: 10.3390/toxins7093465).

71. Pietsch C., Junge R. Physiological responses of carp (Cyprinus carpio L.) to dietary exposure to zearalenone (ZEN). Comparative Biochemistry and Physiology Part C: Toxicology \& Pharmacology, 2016, 188: 52-59 (doi: 10.1016/j.cbpc.2016.06.004).

72. Pietsch C., Junge R., Burkhardt-Holm P. Immunomodulation by zearalenone in carp (Cyprinus carpio L.). Biomed Research International, 2015, 2015: 420702 (doi: 10.1155/2015/420702).

73. Pietsch C. Zearalenone (ZEN) and its influence on regulation of gene expression in carp (Cyprinus carpio L.) liver tissue. Toxins, 2017, 9(9): 283 (doi: 10.3390/toxins9090283).

74. Huang C., Wu P., Jiang W.-D., Liu Y., Zeng Y.-Y., Jiang J., Kuang S.Y., Tang L., Zhang Y.A., Zhou X.-Q., Feng L. Deoxynivalenol decreased the growth performance and impaired intestinal physical barrier in juvenile grass carp (Ctenopharyngodon idella). Fish and Shellfish Immunology, 2018, 80: 376-391 (doi: 10.1016/j.fsi.2018.06.013).

75. Huang C., Feng L., Jiang W.-D., Wu P., Liu Y., Zeng Y.-Y., Jiang J., Kuang S.Y., Tang L., Zhou X.-Q. Deoxynivalenol decreased intestinal immune function related to NF- $\mathrm{B}$ and TOR signalling in juvenile grass carp (Ctenopharyngodon idella). Fish and Shellfish Immunology, 2019, 84: 470-484 (doi: 10.1016/j.fsi.2018.10.039).

76. Huang C., Feng L., Liu X.-A., Jiang W.-D., Wu P., Liu Y., Jiang J., Kuang S.-Y., Tang L., Zhou X.-Q. The toxic effects and potential mechanisms of deoxynivalenol on the structural integrity of fish gill: Oxidative damage, apoptosis and tight junctions disruption. Toxicon, 2020, 174: 32-42 (doi: 10.1016/j.toxicon.2019.12.151).

77. Wang Y.-L., Zhou X.-Q., Jiang W.-D., Wu P., Liu Y., Jiang J., Wang S.-W., Kuang S.-Y., Tang L., Feng L. Effects of dietary zearalenone on oxidative stress, cell apoptosis, and tight junction in the intestine of juvenile grass carp (Ctenopharyngodon idella). Toxins, 2019, 11(6): 333 (doi: 10.3390/toxins11060333).

78. Sanden M., Jørgensen S., Hemre G.-I., Ørnsrud R., Sissener N.H. Zebrafish (Danio rerio) as a model for investigating dietary toxic effects of deoxynivalenol contamination in aquaculture feeds. Food and Chemical Toxicology, 2012, 50(12): 4441-4448 (doi: 10.1016/j.fct.2012.08.042).

79. Bakos K., Kovács R., Staszny A., Sipos D.K., Urbányi B., Müller F., Csenki Z., Kovács B. Developmental toxicity and estrogenic potency of zearalenone in zebrafish (Danio rerio). Aquatic Toxicology, 2013, 136-137: 13-21 (doi: 10.1016/j.aquatox.2013.03.004).

80. Scwartz P., Bucheli T.D., Wettstein F.E., Burkhardt-Holm P. Life-cycle exposure to the estrogenic mycotoxin zearalenone affects zebrafish (Danio rerio) development and reproduction. Environmental Toxicology, 2013, 28(5): 276-289 (doi: 10.1002/tox.20718).

81. Modra H., Sisperova E., Blahova J., Enevova V., Fictum P., Franc A., Mares J., Svobodova Z. Elevated concentrations of T-2 toxin cause oxidative stress in the rainbow trout (Oncorhynchus mykiss). Aquaculture Nutrition, 2017, 24(2): 842-849 (doi: 10.1111/anu.12613).

82. Matejova I., Vicenova M., Vojtek L., Kudlackova H., Nedbalcova K., Faldyna M., Sisperova E., Modra H., Svobodova Z. Effect of the mycotoxin deoxynivalenol on the immune responses of rainbow trout (Oncorhynchus mykiss). Veterinarni Medicina, 2015, 60(9): 515-521 (doi: 10.17221/8443-VETMED).

83. Woźny M., Brzuzan P., Wolińska L., Góra M., Łuczyński M.K. Differential gene expression in rainbow trout (Oncorhynchus mykiss) liver and ovary after exposure to zearalenone. Comparative Biochemistry and Physiology Part C: Toxicology \& Pharmacology, 2012, 156(3-4): 221-228 (doi: 10.1016/j.cbpc.2012.05.005).

84. Woźny M., Brzuzan P., Gusiatin M., Jakimiuk E., Dobosz S., Kuźmiński H. Influence of zearalenone on selected biochemical parameters in juvenile rainbow trout (Oncorhynchus mykiss). Polish Journal of Veterinary Sciences, 2012, 15(2): 221-225 (doi: 10.2478/v10181-011-0137-1).

85. El-Sayed Y.S., Khalil R.H., Saad T.T. Acute toxicity of ochratoxin A in marine water-reared sea bass (Dicentrarchus labrax L.). Chemosphere, 2009, 75(7): 878-882 (doi: 10.1016/j.chemosphere.2009.01.049).

86. Gbore F.A., Adewole A.M., Oginni O., Oguntolu M.F., Bada A.M., Akele O. Growth performance, haematology and serum biochemistry of African catfish (Clarias gariepinus) fingerlings fed graded levels of dietary fumonisin B1. Mycotoxin Research, 2010, 26(4): 221-227 (doi: 10.1007/s12550-010-0059-2).

87. Adeyemo B.T., Oloyede T.L., Ogeh A.V., Orkuma C.J. Growth performance and serum lipids profile of Clarias gariepinus catfish following experimental dietary exposure to fumonosin B1. Open Journal of Veterinary Medicine, 2016, 6(8): 127-138 (doi: 10.4236/ojvm.2016.68017).

88. Tola S., Bureau D.P., Hooft J.M., Beamish F.W.H., Sulyok M., Krska R., Encarnação P., Petkam R. Effects of wheat naturally contaminated with Fusarium mycotoxins on growth performance and selected health indices of red tilapia (Oreochromis niloticus $\times$ O. mossambicus). Toxins, 2015, 7(6): 1929-1944 (doi: 10.3390/toxins7061929).

89. Yildirim M., Manning B.B., Lovell R.T., Grizzle J.M., Rottinghaus G.E. Toxicity on moniliformin and fumonisin B1 fed singly and in combination in diets for young channel catfish Ictalurus punctatus. Journal of the World Aquaculture Society, 2000, 31(4): 599-608 (doi: 10.1111/j.1749- 
7345.2000.tb00909.x).

90. Nguyen A.T., Manning B.B., Lovel R.T., Rottinghaus G.E. Responces of Nile tilapia (Oreochromis niloticus) fed diets containing different concentrations of moniliformin or fumonisin B1. Aquaculture, 2003, 217(1-4): 515-528 (doi: 10.1016/S0044-8486(02)00268-5).

91. Асраркулова А.С., Булушова Н.В. Пшеничный глютен и его гидролизаты. Возможные направления практического использования (обзор). Биотехнология, 2018, 34(4): 6-17.

92. Zachariasova M., Dzuman Z., Veprikova Z., Hajkova K., Jiru M., Vaclavikova M., Pospichalova M., Florian M., Hajslova J. Occurrence of multiple mycotoxins in European feedingstuffs, assessment of dietary intake by farm animals. Animal Feed Science and Technology, 2014, 193: 124-140 (doi: 10.1016/j.anifeedsci.2014.02.007).

93. Косарева Т.В., Васильев А.А., Гоголкин А.А. Использование зернового сорго в индустриальном рыбоводстве. Вестник Саратовского Госуниверситета им. Н.И. Вавилова, 2014, 2: $15-18$.

94. Правдин В., Ушакова Н., Пономарев С., Кузнецов Ф. Льняной жмых для карповых и осетровых рыб. Комбикорма, 2009, 8: 58-59.

95. Сорокина Н.В., Лозовский А.Р. Влияние комбикорма с тыквенным жмыхом на рост и физиологическое состояние стерляди. Естественные науки, 2010, 4(33): 74-79.

96. Кононенко Г.П., Буркин А.А. Вторичные метаболиты микромицетов в растениях семейства Fabaceae рода Trifolium. Известия РАН. Серия биологическая, 2018, 2: 150-157 (doi: $10.7868 / \mathrm{S} 0002332918020030)$.

97. Буркин А.А., Кононенко Г.П., Георгиев А.А., Георгиева М.Л. Токсичные метаболиты микромицетов в бурых водорослях семейств Fuсасеае и Laminariaceae из Белого моря. Биология моря, 2021, 47(1): 40-44 (doi: 10.31857/S0134347521010022).

98. Пономорев С.В., Гамыгин Е.А., Канидьев А.Н. Физиологические основы создания полноценных комбинированных кормов с учетом этапности развития организма лососевых и осетровых рыб. Вестник АГТУ. Серия: Рыбное хозяйство, 2010, 1: 132-139.

99. Пирязева Е.А. Распространенность грибов рода Penicillium Link в сырье для производства комбикормов. Российский журнал «Проблемы ветеринарной санитарии, гигиены и экологии», 2018, 4(28): 23-26.

100. Стратегия развития аквакультуры в Российской Федерации на период до 2030 года. Проект. Режим доступа: http://fish.gov.ru/files/documents/files/proekt-strategiya-2030.pdf. Без даты.

101. Fuchs R., Appelgren L.E., Hult K. Distribution of ${ }^{14} \mathrm{C}$-ochratoxin A in the rainbow trout (Salmo gairdneri). Acta Pharmacologica et Toxicologica (Copenh.), 1986, 59(3): 220-227 (doi: 10.1111/j.1600-0773.1986.tb00158.x).

102. Guan S., He J., Young J.C., Zhu H., Li X.-Z., Ji C., Zhou T. Transformation of trichothecene mycotoxins by microorganisms from fish digesta. Aquaculture, 2009, 290: 290-295 (doi: 10.1016/j.aquaculture.2009.02.037).

103. Bernhoft A., Høgåsen H.R., Rosenlund G., Ivanova L., Berntssen M.H.G., Alexander J., Sundstøl Eriksen G., Kruse Fæste C. Tissue distribution and elimination of deoxynivalenol and ochratoxin A in dietary exposed Atlantic salmon (Salmo salar). Food Additives and Contaminants. Part A, 2017, 34(7): 1211-1224 (doi: 10.1080/19440049.2017.1321149).

104. ТР ЕАЭС 040/2016. Технический регламент Евразийского экономического союза (ЕАЭС) «О безопасности рыбы и рыбной продукции»: принят решением Совета Евразийской экономической комиссии от 18.10.2016. № 162. Режим доступа: http://docs.cntd.ru/document/420394425. Без даты.

\section{Всероссийский НИИ ветеринарной санитарии, гигиены и экологии - филиал ФГБНУ ФНЦ ВИЭВ РАН, 16 ноября 2020 года}

123022 Россия, г. Москва, Звенигородское ш., 5,

e-mail: kononenkogp@mail.ru $\bigotimes$, mitya_anest@mail.ru, ustpuma@list.ru

Sel'skokhozyaistvennaya biologiya [Agricultural Biology], 2021, V. 56, № 2, pp. 261-278

\section{RISK OF FISH MYCOTOXICOSIS IN AQUACULTURE (review)}

\section{G.P. Kononenko ${ }^{凶}$, D.A. Onischenko, M.I. Ustyuzhanina}

All-Russian Research Institute of Sanitary, Hygiene and Ecology - Branch of FSC ARRIEV RAS, 5, Zvenigorodskoe sh., Moscow, 123022 Russia, e-mail kononenkogp@mail.ru ( $\square$ corresponding author), mitya_anest@mail.ru, ustpuma@list.ru

ORCID:

Kononenko G.P. orcid.org/0000-0002-9144-615X

Onishchenko D.A. orcid.org/0000-0003-2534-9455

The authors declare no conflict of interests

Received November 16, 2020

Ustyuzhanina M.I. orcid.org/0000-0001-7405-7577

doi: 10.15389/agrobiology.2021.2.261eng 


\begin{abstract}
Modern fish aquaculture is a large-scale and rapidly developing industry of global production (FAO, 2018). In order to improve the quality of the products produced, an active search is underway for effective ways to control the safety of artificial feeds (J. Bostock et al., 2010). Based on the results of monitoring projects carried out in Argentina, Brazil, the United States, China, Korea and Central European countries (C. Pietsch et al., 2013; B.T.C. Barbosa et al., 2013; M. Greco et al., 2015; L. Pinotti et al., 2016), the situation of contamination of fish feed with mycotoxins is recognized as extremely serious both in terms of prevalence and content, and in terms of combined occurrence (I. Matejova et al., 2017; C. Pietsch, 2019). For the Russian fishery, which in recent years has become a multi-destination, specialists of academic and university science, as well as industry research institutes proposed feed rations that account for age and species characteristics of fish (J.A. Zheltov, 2006; Y.V. Sklyarov, 2008), and discussed in detail the problem of microbial contamination (I.V. Burlachenko, 2008). In the Russian Federation, mandatory requirements for compliance with quality and safety indicators have been introduced for raw materials and finished feed products (GOST 10385-2014) and a modern methodological base for mycotoxicological control has been created (GOST 31653-2012, GOST 31691-2012, GOST 32587-2013, GOST 34108-2017, GOST R 511162017).The purpose of this review is to update information on mycotoxin contamination of domestic raw materials for the production of aquafeeds, to generalize world data on the nature of acute action of the most occurring contaminants, as well as to analyze clinical signs, pathologic-anatomical and biochemical changes accompanying chronic fish mycotoxicosis. In recent years, we have received convincing evidence that the group of the most likely contaminants of raw ingredients - wheat, barley and corn flour, bran, sunflower cake and meal - includes T-2 toxin, deoxynivalenol, fumonisins of group B and zearalenone, related to fusariotoxins, as well as alternariol, ochratoxin A, citrinin, cyclopiazonic acid, mycophenolic acid and emodin (G.P. Kononenko et al., 2018, 2019). Analysis of world data on experimental mycotoxicoses of different age groups of common carp (Cyprinus carpio), channel catfish (Ictalurus punctatus), white Amur (Ctenopharyngodon idellus), Nile tilapia (Oreochromis niloticus), rainbow trout (Oncorhynchus mykiss), Atlantic salmon (Salma salar), shows that fusariotoxins should be considered as key risk factors and efforts should continue to refine their safe thresholds. Intoxications caused by ochratoxin A remain insufficiently studied, and the situation with regard to other possible feed contaminants is unclear. Reasonable proposals for regulation in fish feed were reported only for T-2 toxin for common carp (V.T. Galash, 1988), for deoxynivalenol - for white Amur (C. Huang et al., 2018, 2019, 2020) and Atlantic salmon (A. Bernhoft et al., 2018), for fumonisin B1 - for channel catfish (M.N. Li et al., 1994, S. Lumlertdacha et al., 1995). Data on the degree of retention of these mycotoxins in fish tissues is limited (C. Pietsch et al., 2014, 2015; A. Ananter et al., 2016), and therefore regulations on product residues have not yet been adopted. However, the search for new approaches to correctly assess the consequences of their negative effects and transmission to fish products continues, and this leaves no doubt that a solution will be found.
\end{abstract}

Keywords: aquaculture, fish mycotoxicoses, feed raw materials, combined feeds, mycotoxins. 